INTERNATIONAL JOURNAL OF RESEARCHES IN BIOSCIENCES, AGRICULTURE \& TECHNOLOGY ( ) VISHWASHANTI MULTIPURPOSE SOCIETY (Global Peace Multipurpose Society) R. No. MH-659/13(N) www.vmsindia.org

\title{
SURVIVAL STUDIES OF BACTERIAL PATHOGENS AND THEIR IMMUNIZATION EFFECT ON HAEMATOLOGIAL INDICES IN HEALTHY AND INFECTED FISH (Channa marulias) FROM WAINGANGA RIVER OF GADCHIROLI DISTRICT (M.S)
}

\author{
1Bodhe Y.G., ${ }^{1}$ Wadhai V.S. and 2 Bhandari P.R. \\ ${ }_{1}^{1}$ Sardar Patel Mahavidyalaya, Chandrapur (M.S) India \\ 2Sevadal Mahila College Nagpur (M.S) India \\ Email: yuuraj.bodhe@rediffmail.com
}

\begin{abstract}
A study was conducted aiming at the isolation of human pathogenic bacteria in gills, intestines, mouth and the skin of apparently healthy and infectious fish Channa marulias and to investigate the reference ranges for haematological and serum biochemical values of Channa marulias. Blood samples were then taken from the caudal vein of fishes. Haematological parameters such as haemoglobin (Hb), total leucocyte count (TLC), packed cell volume (PCV), four parameters namely $\mathrm{RBC}, \mathrm{Hb}(\mathrm{p}<0.05)$ and WBC $(\mathrm{p}<0.05)$ revealed significant difference between healthy and infected fish. The following human pathogenic bacteria were isolated Escherichia coli, Staphylococcus aureus, Salmonella typhi, Pseudomonas aeruginosa, Vibrio cholera and Shigella dysenteriae. The mean bacterial load of the isolates was found to be markedly higher than the recommended public health and standard value of $5.0 \mathrm{x} 106$ $\mathrm{CFU} / \mathrm{ml}$ which has been adopted by many countries.
\end{abstract}

$\underline{\text { Key words: - Channa marulias, Bacterial pathogens, Wainganga river }}$

\section{Introduction:}

Channa marulias is native to South Asia. In South India it is commonly found in reservoirs of eastern Vidarbha region. It is a faster growing fish than most of the other species of the genus. It is a carnivorous species. It is marketed live and fetches high prices in the market. Fishes are well known for their nutritional value. Healthy fishes are prized for their table quality. However, this quality is influenced by several operational environmental factors. Often, they are prone to microbial and parasitic infections. A well known economic loss to the fish industry was the major outbreak of bacterial infection in major carps. The causative agents of the severe acute infectious abdominal dropsy outbreak in Indian major craps. Cirrhinus mrigala was reported Shome et al (1996). However, the first observation on diseases in Indian major carps was found in descending order of susceptibility on Catla catla, Cirrhinus mrigala and Labeo rohita (Gopalakrishnan 1981). Other well recorded cases have been the severe epidemic due to the diseased condition of Eropean carps (Snieszko 1954; Van Dujin 1956).

Fish is a vital source of food for people. The advantage of fish as food is as a result of its easy digestibility and high nutritional value. However fish are susceptible to a wide variety of bacterial pathogens, most of which are capable of causing disease and are considered by some to be saprophytic innature. Suggested that the type of microorganisms that are found associated with particular fish depends on its habitat (Claucas, I.J., Ward, A.R. 1996).

(Kvenberg, E.J.1991 And Rodricks, E.G. 1991) classified the bacterial pathogens associated with fish as indigenous and nonindigenous. The non-indigenous contaminate the fish or the habitat one way or the other and examples include Escherichia coli, Clostridium botulinum, Shigella dynteriae, Staphylococcus aureus, Listeria monocytogens and Salmonella. The indigenous bacterial pathogens are found naturally living in the fish's habitat for example Vibrio species and Aeromonas species. The bacteria from fish only become pathogens when fish are physiologically unbalanced, nutritionally deficient, or there are other stress conditions, i.e., poor water quality, overstocking, which allow opportunistic bacterial infections to prevail. Pathogenic and potentially pathogenic bacteria associated with fish and shell fish include Mycobacteium, Streptococcus spp., Vibrio spp., Aeromonas spp., Salmonella spp. and others. 
Other studies have also demonstrated the presence of indicator micro-organisms of faecal pollution, opportunistic and pathogenic bacteria to humans in fish samples .There are often bacterial species that are facultative pathogenic for both fish and human beings and maybe isolated from fish without apparent symptoms of the disease. Human infections caused by pathogens transmitted from fish or the aquatic environments are quite common and depend on the season, patients' contact with fish and related environment, dietary habits and the immune system status of the individual. Transmission of the pathogens can be through the food or the handling of the fish. There have been great economic losses reported due to food borne illness such as dysentery and diarrhea resulting from consumption of contaminated fish. The microbial association with fish compromises safety and the quality for human consumption; critical is when the microorganisms are opportunistic and / or pathogenic in nature. The risks of contracting food borne diseases by the residents from the surrounding communities that are using the fish from above mentioned sources may be high. These circumstances prompted this research to investigate the presence of any human bacterial pathogens in the fish that was being caught from the river (Mhango, M., Mpuchane, S.F. and Gashe, B. A. 2010).

Haematological and biochemical test has not widely applied for diagnosis of piscine medicine but these tests could be a suitable diagnostic tool for monitoring physiological and pathological changes in fishes. Different factors such as season, water contamination, physicochemical parameters of the water, stressors, age and sex, and fish species affect the haematological parameters. One of the difficulties in assessing the state of health of natural fish population has been the lack of reliable references of the normal condition. In pursuant to this goal, many fish physiologists have turned to studies of haematology, probably because it has provided a valuable diagnostic tool in evaluating human health. Determination of haematological parameters can provide substantial diagnostic information, once standardized reference values are established. Moreover, recent attention has been given to the biochemical characterization of fish blood as an internal index (Hrubee, TC; 2000).

\section{Materials and Methods:}

\section{Study Area}

This study was conducted on fish species collected for studies of bacterial pathogens and their immunization effect on haematologial and biochemical indices in healthy and infected fish from Wainganga river In Gadchiroli district the river flows nearby Armori tehsil. The fish samples were collected from a freshwater during the period October 2015 to February 2016. The numbers of fishes caught were transported on the same day in a container filled with pond water to the laboratory and the analysis was carried out. A total of 10 adult specimens of the species having mean length $20.14 \pm 0.40 \mathrm{~cm}$, breadth $3.63 \pm 0.08$ $\mathrm{cm}$ and weight $125.20 \pm 4.18 \mathrm{~g}$ were utilized in the present investigation.

\section{Laboratory Analysis Fish samples}

Forty fish samples were collected from Wainganga River between the periods of October 2015 to February 2016. Twenty samples of Channa marulias were collected aseptically and immediately from areas separately and transported in a thermal bag to the laboratory and processed within $3 \mathrm{hrs}$ of acquisition, and samples were kept in the refrigerator $\left(4-8^{\circ} \mathrm{C}\right)$.

\section{Sample preparation}

Sample preparation was made using the method described by. About $10 \mathrm{~g}$ of the fish sample was cut from the head, middle and tail regions with a sterile knife. The cut samples were crushed into small pieces in a sterile mortar with about $10 \mathrm{ml}$ sterile water. From the crushed sample, $1 \mathrm{ml}$ aliquot volume was measured out and homogenized in a clean, dry sterile beaker containing $9 \mathrm{ml}$ of distilled water giving a 1:10 dilution. This was done for the 40 fish samples.

\section{Sampling}

The bacterial counts on the external surfaces, intestines and tissue were estimated as follows: 


\section{Skin Surfaces}

Sample from different locations of the skin of 40 raw fish was taken by rubbing the sterilized cotton swab over the skin and then inoculated into $9 \mathrm{ml}$ of Nutrient broth, MacConkey broth and Selenite F broth which are dispensed in separate tubes. 10 fold serial dilution of the bacterial suspension inoculated in peptone water was prepared induplicate and viable aerobic bacterial counts were enumerated using $0.1 \mathrm{ml}$ and $1 \mathrm{ml}$ inoculums in standard plate count agar as described by (Slaby, B.M., Martin, R.E., Ramsdell, and G.E.1981) and then incubated at $37^{\circ} \mathrm{Cfor} 48 \mathrm{hrs}$.

\section{Intestines, Gills $\&$ Tissues}

$1 \mathrm{~g}$ of the fish sample was dissected out, blended and mixed properly in a mortar. It was aseptically transferred to a sample bottle containing $9 \mathrm{ml}$ of $0.1 \%$ sterile peptone water. The bottle was closed and shaken thoroughly for 10 minutes and allowed to stand for 20 minutes, after which a 10 fold serial dilution was carried out in duplicates and viable aerobic bacterial counts were enumerated in standard plate count agar after incubation at $37^{\circ} \mathrm{C}$ for 48 hrs as described by (Rodricks, E.G. 1991). Coliforms organisms and gram negative enteric bacteria counts were determined using pour plate method with MacConkey agar, EMB Agar respectively. Pseudomona isolation Agar for Pseudomonas spp. Salmonella spp. and Shigella spp. were enumerated using Salmonella Shigella Agar (SSA) and Thiosulphate Citrate Bile Salt Sucrose (TCBS) agar for pathogenic Vibrio spp. The plates were incubated at $37^{\circ} \mathrm{C}$ for 24 hrs. The observed colony growth were counted using Coulter ${ }^{\mathrm{TM}}$ Colony counter according to plate count method. Identification of the organisms was done using the phenotypic and biochemical characteristics as described by and (Slaby, B.M., Martin, R.E., Ramsdell, G.E.1981).

\section{Estimate of mean colony forming unit per gram (CFUg-1)}

The mean colony forming unit per gram (CFU g-1) denoted by (x) was calculated as $\Sigma f x / \Sigma f$, where $\Sigma f x$ is the sum of the products of number of colonies and the colony forming unit per gram; while $\Sigma f$ is the summation of the number of colonies.

\section{Hematological Examination:}

For hematological examination ten healthy and ten infected fishes were used. Blood was drawn from caudal peduncle into $\mathrm{Di}$ Potassium EDTA containing tube by the process as described by (Hrubc \& smith 2000). RBCs and WBCs were counted by haemocytometer and values were calculated as $10^{6} / \mathrm{mm}^{3}$ and $10^{3} / \mathrm{mm}^{3}$ (Wintrobe, 1967). Hemoglobin content was determined by using hemoglobin test kit (DIAGNOVA, Ranbaxy, India). The blood film was prepared and stained with Giemsa stain for morphology, micrometry and differential count of leucocytes. All the values of healthy and infected fish were analyzed by students ' $\mathrm{t}$ ' test.

\section{Results:}

In this study, for all the fish samples ranged between $1.06 \times 10^{6}$ and $21.54 \times 10^{6} \mathrm{cfu} / \mathrm{ml}$ as shown in Table No.1. Out of the 40 fish samples analyzed, for the skin had the highest number of bacteria with $21.54 \mathrm{x}$ $10^{6} \mathrm{cfu} / \mathrm{ml}$ in C. marulias.

Table No. 1: Count of bacteria present at different parts of examined sample fish.

\begin{tabular}{|c|c|c|c|c|c|c|c|c|}
\hline Fish & Parts & Coliforms & E.coli & S. aureus & P.aueruginosa & $\begin{array}{l}V . \\
\text { cholerae }\end{array}$ & S. typhi & S.dysenteriae \\
\hline & & $(\mathrm{cfu} / \mathrm{ml})$ & $(\mathrm{cfu} / \mathrm{ml})$ & $(\mathrm{cfu} / \mathrm{ml})$ & $(\mathrm{cfu} / \mathrm{ml})$ & $(\mathrm{cfu} / \mathrm{ml})$ & $(\mathrm{cfu} / \mathrm{ml})$ & $(\mathrm{cfu} / \mathrm{ml})$ \\
\hline & & $10^{6}$ & $10^{6}$ & $10^{6}$ & $10^{6}$ & $10^{6}$ & $10^{6}$ & $10^{6}$ \\
\hline \multirow{4}{*}{$\begin{array}{l}\text { Channa } \\
\text { marulias }\end{array}$} & Intestine & 8.50 & 12.5 & 6.10 & 16.22 & 8.19 & 4.17 & 1.06 \\
\hline & Gill & 11.46 & 14.04 & 4.82 & 14.49 & 2.84 & 4.18 & 3.64 \\
\hline & Skin & 21.54 & 11.08 & 8.46 & 18.78 & 3.24 & 5.24 & 1.26 \\
\hline & Mouth & 16.64 & 15.26 & 4.48 & 13.84 & 2.48 & 4.16 & 4.14 \\
\hline
\end{tabular}


Table No.1 revealed the isolation of Pseudomonas $s p$. with the skin having the highest number count to be $18.78 \times 10^{6}$ $\mathrm{cfu} / \mathrm{ml}$. The S.dysenteriae isolated had the lowest count to be $1.06 \times 10^{6} \mathrm{cfu} / \mathrm{ml}$ from the skin of $C$. marulias as compared with other parts of fish. The intestine is the most colonized part of E.coli examined areas in the fish with count to be $12.50 \times 10^{6} \mathrm{cfu} / \mathrm{ml}$, while the lowest count was examined areas in the fish with count to be C. marulias $\left(1.06 \times 10^{6} \mathrm{cfu} / \mathrm{ml}\right)$.

The gills likewise showed possible colonization but in the lowest count as compared to other parts. Isolation of Vibrio $s p$. on the intestine of fishes. Coliforms isolation showed the highest count in $C$. marulias for skin $\left(21.54 \times 10^{6} \mathrm{cfu} / \mathrm{ml}\right)$.

The mouth and gills were also heavily populated by $E$. coli with the highest exhibited in the gills of $C$. marulias. Staphylococcus aureus had a low isolation rate in all samples analyzed as generally compared with other isolated organisms that had the lowest counts. The human bacterial pathogens that were isolated and identified include Escherichia coli, Pseudomonas aueriginosa, Shigella dysenteriae, S. aureus, Coliforms, S. typhi and indicated in the Table No.1.

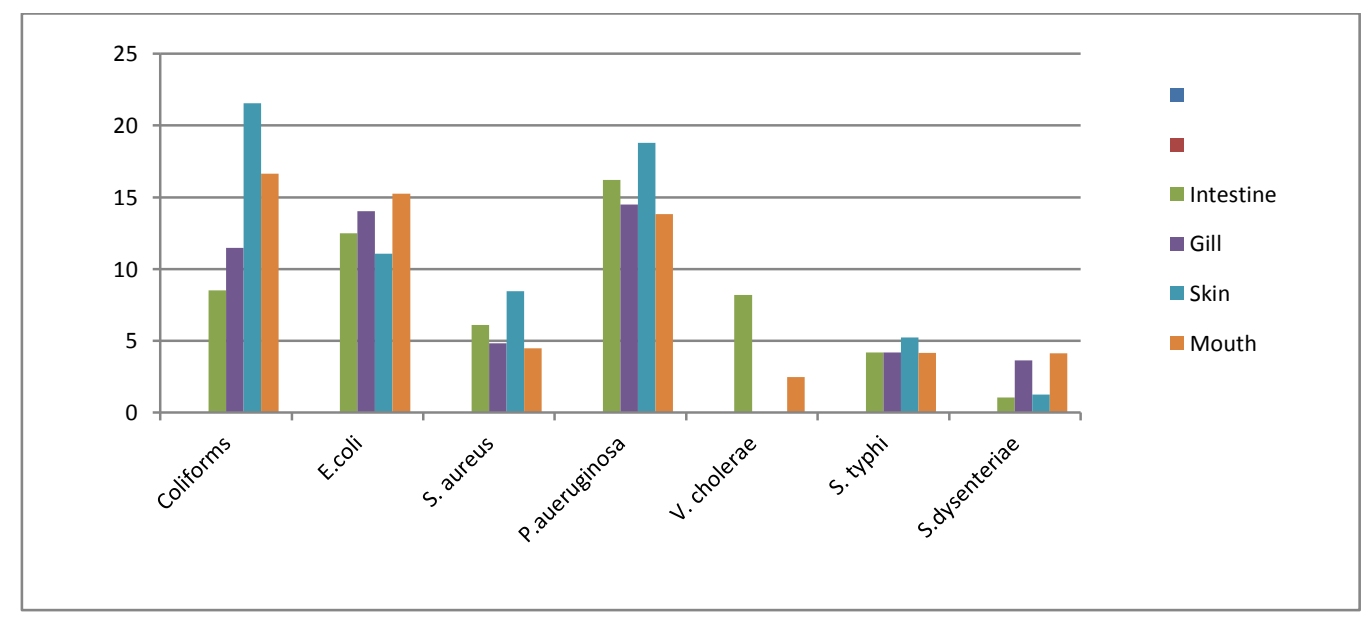

Figure-1. Bacterial count in various parts of fish Channa morulias

Table-2. Haematological parameters of Normal and Infected Channa marulias.

\begin{tabular}{|c|c|c|c|c|c|c|c|}
\hline Sr. No. & Parameters & \multicolumn{2}{|l|}{ units } & Normal fish & infected fish & $\begin{array}{l}\text { Percentage } \\
\text { change }\end{array}$ & Significance \\
\hline 1 & Haemoglobin & \multicolumn{2}{|l|}{$\mathrm{g} / 100 \mathrm{ml}$} & $12.27 \pm 0.36$ & $8.73 \pm 0.47$ & $28.85 \%$ & $\mathrm{P}<0.05$ \\
\hline 2 & RBC count & \multicolumn{2}{|l|}{$106 / \mathrm{mm}^{3}$} & $5.49 \pm 0.23$ & $4.60 \pm 0.13$ & $16.21 \%$ & $\mathrm{P}<0.05$ \\
\hline 3 & WBC count & \multicolumn{2}{|l|}{$10^{3} / \mathrm{mm}^{3}$} & $3.44 \pm 0.14$ & $6.59 \pm 0.17$ & $-91.56 \%$ & $\mathrm{P}<0.05$ \\
\hline \multicolumn{8}{|c|}{ Differential count of leucocytes } \\
\hline 1 & \multicolumn{2}{|l|}{ Neutrophils } & $\%$ & $17.99 \pm 0.20$ & $26.52 \pm 0.18$ & $-47.41 \%$ & $\mathrm{P}<0.05$ \\
\hline 2 & \multicolumn{2}{|l|}{ Eosinophils } & $\%$ & $71.97 \pm 0.30$ & $62.85 \pm 0.26$ & $12.66 \%$ & $\mathrm{P}<0.05$ \\
\hline 3 & \multicolumn{2}{|l|}{ Lymphocytes } & $\%$ & $2.60 \pm 0.16$ & $4.65 \pm 0.21$ & $-78.84 \%$ & $\mathrm{P}<0.05$ \\
\hline 4 & \multicolumn{2}{|l|}{ Monocytes } & $\%$ & $1.87 \pm 0.07$ & $2.84 \pm 0.10$ & $-51.87 \%$ & $\mathrm{P}<0.05$ \\
\hline
\end{tabular}

Mean values $\pm S E$, (-) Decrease, (+) Increase 


\section{Hemoglobin content:}

In normal fish hemoglobin content was found to be $12.13 \pm 0.36 \mathrm{~g} / 100 \mathrm{ml}$ while in infected fish there was observed a significant decrease ie.8.73 $\pm 0.47 \mathrm{gm} / 100 \mathrm{ml}$.

\section{Total RBCs:}

The mean values of erythrocytes in healthy fish were found to be $5.49 \pm 0.2310^{6} / \mathrm{mm}^{3}$ which is significantly decreased down to $4.60 \pm 0.1310^{6} / \mathrm{mm}^{3}$ in infected fish.

\section{Total WBCs:}

In healthy fish the mean values of White blood cells were found to be $3.44 \pm 0.14$ $10^{3} / \mathrm{mm}^{3}$ and in infected fish values were significantly increased to 6.69. \pm 0.17 $10^{3} / \mathrm{mm}^{3}$.

\section{Differential count of leucocytes:}

The mean value percentage in healthy fish of Neutrophils was found to be $17.99 \pm 0.20$ which rise to $26.52 \pm 0.18$ in infected fish. Eosinophils were $71.97 \pm 0.30$ which is significantly decreased down to $62.85 \pm 0.26$. Lymphocytes and Monocytes percentage was $2.60 \pm 0.16$ and $1.87 \pm 0.07$ in healthy fish. In infected fish lymphocytes increases to $1.87 \pm 0.073 .35 \pm 0.16$ and Monocytes decreased down to $2.84 \pm 0.10$ (Table-2.)

During the study bacterial pathogens have been isolated from Channa marulias. Hematological examination of infected $C$. marulias revealed that there has been considerable increase (28.85\%) in hemoglobin content. Increase in hemoglobin trend may be a result of swelling of RBC as well as poor mobilization of hemoglobin from spleen. Erythrocytes percentage was considerably decreased to $(16.21 \%)$. In WBCs (-91.56\%) decrease was observed Neutrophils and lymphocytes showed significant increase of (-47.41\%and (12.66\%) respectively. An increase in the percentage of granulocytes indicates infection in fishes. The increase in number of granulocytes in infected fish may be due to increase in tissue damage by pathogens or other stress factors also reported similar trend of change in blood profile as reported in present study.

\section{Discussion:}

A high population of bacteria in food indicates the general quality of the food and the degree of spoilage it might have undergone. The occurrence of total bacterial counts of many of the samples investigated having $>5 \mathrm{X} 10^{6} \mathrm{CFU} / \mathrm{g}$ raises concern about the hygienic status of the production and point of sale environment. The results from this study and according to published microbiological guidelines as cited by (Gilbert, R.J., de Louvois, J. and Donovan, T.1996) suggest that the microbiological quality of the fish examined is unacceptable and pose a potential risk to public health. The diversity of potential pathogens from the samples of fish is of concern particularly at a time when many in our communities are immunologically compromised as a result of various illnesses. These opportunistic and pathogenic bacteria were also previously isolated by several other researchers from fish (Mhango, M., Mpuchane, S.F. and Gashe, B. A. 2010).

The fish in this study harbored human disease causing organisms that cause diseases such as food poisoning, diarrhea, typhoid fever and Shigellosis. (Claucas, I.J., Ward, A.R.1996). Suggested that when present in food, pathogens such as $S$. aureus, Salmonella, Shigella and Pseudomonas are most likely to cause foodborne diseases. The high incidence of Salmonella in the fish from the river is a major health concern. In addition to salmonellae, the presence of diverse enteric bacteria in fish indicates the contamination representing a potential hazard to human health especially those who are sick or are on immunosuppressive drugs.

Severe regulations and monitoring activities coupled with food safety training of suppliers (fishermen and traders) and ultimately the consumers on various aspects of Good Hygiene Practice (GHP), Good Manufacturing Practice (GMP) and HACCP is strongly recommended. The presence of faecal coliforms in fish demonstrates the level of pollution of their environment because Coliforms are not the normal of bacteria in fish. Of the organisms that were isolated and identified that is S.typhi, S.aureus, S.dysenteriae and E.coli are non-indigenous pathogens that contaminate fish or fish habitats in one way or the other (Kvenberg, E.J.1991).

The isolation of Salmonella, Shigella, and E.coli indicate faecal and environmental pollution. Coliforms such as E.coli are 
usually present where there has been faecal contamination from warm blooded animals (Chao, K.K., Chao, C.C. and Chao, W.L.2003). The organism E.coli is recognized as the reliable indicator of faecal contamination in small numbers and in large number sit is an indicator of mishandling. Of concern is the fact that the high bacterial loads found in the raw fish at the source point are most likely to have a multiplier effect as the caught fish are poorly handled and stored until they are consumed. In similar studies, Escherichia coli, Pseudomonas aueriginosa, Shigella dysenteriae, Staphylococcus aureus and Salmonella typhi were isolated from the gills, intestines. This was attributed to the heavy load of sewage disposal into the seas which could act as a suitable environment for the growth and survival of the human pathogens.

\section{Conclusion:}

Seven human bacterial pathogens i.e. Escherichia coli, Pseudomonas aueriginosa, Shigella dysenteriae, Staphylococcus aureus, vibrio cholerae, and Salmonella typhi were isolated from the two fish species Channa marulias collected from Wainganga river of Gadchiroli District.. The presence, in large populations of these bacterial pathogens indicates high levels of faecal contamination in the river. The presence of enteric bacteria may be attributed to faecal contamination due to improper sewage disposal and or water pollution. The fish act as a reservoir of human pathogens and the presence of highly pathogenic agents such as Salmonella, Shigella species and of opportunistic pathogens is a potential health risk/hazard to human beings and may cause diseases to susceptible individuals especially the immunecompromised consumers. Moreover the recoveries of various organisms, which are potentially pathogenic to humans, in the fish suggest that if they are improperly handled, undercooked or consumed raw may contribute to the spread of the pathogens in the community. Further examination of fish especially for the presence of pathogens, during handling, storage and up to the very point of consumption is needed for the protection and maintenance of community health by keeping food borne diseases to a minimum.

As the bacteria are species specific parasites, it was found from the present study that bacteria are highly pathogenic to fresh water ornamental fish C. marulias causing parasitism. There may be certain toxins present in given species of bacteria which cause pathogenesis in fish lead to change in hematological parameters and varying degree of destruction in the tissue which leads to mortality of fish.

\section{References:}

Banerjee, V and RP Bhagat: Haematology of Indian fresh water eel Amphiponoucuchia (Ham.): Erythrocyte count and related parameters with special reference to body length sex and season. Comp. Physiol. Ecol, 1986, 11(2), 21-27.

Bruno DW: Changes in serum parameters of rainbow trout Salmo gaidnerie R.L. Atlantic salmo, Salmo salar L., infected with Renibacterium salmoninarum. $J$ of Fish Dis.1980, 2.297-311. 4.

Chauhan R: Studies on conidial fungi isolated from some fresh water fishes. Int. $j$. of Advanced life sciences, 2013, vol-6, (4).pp.131-135.

Chauhan R, Beigh AH and Bhatt MH, Histopathological manifestations in commercially important fish, Clarias batrachus (1.) found infected with saprolegnia diclina. Indo. Am. J. of Pharm. Res. 2014b, (4) 2, pp.1168-1172.

Claucas, I.J., Ward, A.R.1996. Postharvest Fisheries Development: A Guide to Handling, Preservation, Processing and Quality. Charthan Maritime, Kent ME4 4TB, United Kingdom. Bergey's Manual of Determinative Bacteriology. 6th Edition 1948.The Williams and Wilkins Co., Baltimore.

Chao, K.K., Chao, C.C. and Chao, W.L.2003. Suitbility of the traditional microbial indicators and their enumerating methods in the assessment of fecal pollution of subtropical freshwater environments. Journal of Microbiology Immunological Infection.36, pp 288-293.

Gopalakrishnan VJ (1961). Observation on Infectious dropsy of Indian major carps and its experimental induction. Jr. Sci Ind Res. 20(C); 357-358.

Gilbert, R.J., de Louvois, J. and Donovan, T.1996. Microbiological guidelines for some ready to eat foods sampled at the point of sale. PHLS Microbiology Digest. 13:41-43.

Hatai K: Studies on pathogenic agents of Saprolegniasis in fresh water fishes. Special 
Re Nagasaki Pref. Inst. Fish.1980, No. 8, 95 p.

Hatai $K$, Nakamura $K$, Rha SA, Yuasa $K$ and Wada S: Aphanomyces Infection in Dwarf Gourami (Colisa lalia) Division of Fish Diseases, Nippon Veterinary and Animal Science University, 1994, 1-7-1 KyonanCho, Musashino, Tokyo 180, Japan.

Haltingh,J and Du Toil: A study of blood constituents of two species of mud fish .1973b.J.Comp.Biochem,Physiol., 46 ,613617.

Hurbee TC and Smith SA: Haematology of fish. In Schalm's Veterinary Haematology, 5 th

Edition Edited by Feldman, B, F .Zinki, J.G and Jain, N.C. Lippincott Williams and Wilkins (USA), 2000, 34 . $1120-1125$.

Hussian MMA, Hassan WH and Mahmood MA: Pathogenicity of Achlya proliferoids and Saprolegnia diclina (Saprolegniaceae) associated with saprolegniasis outbreaks in cultured Nile Tilapia (Oreochromis niloticus). World J. of Fish and Marine Science, 2013, 5 (2); 188- 193.

Iwama, G. K., G.L Geer and D. J. Randall. 1986. Changes in selective haematological parameters in juvenile Chinook salmon subjected to a bacterial challenge and toxicant. J. Fish. Biol. 28, 563-573.

Kvenberg, E.J.1991. Non-indegenous Bacterial Pathogen, In: Microbiology of Marine Food Products. (eds) Donn,R., Wand Cameron, H., Van Nostrand Reinhold, New York,pp.263-291.

Laxmareddy B and Benarjee, G: Intestinal histopathology of trematode infected fish, channa striatus. 2013. Biolife. 1(1), 29-31.

Mhango, M., Mpuchane, S.F. and Gashe. B. A. 2010. Incidence of indicator organisms, opportunistic and pathogenic bacteria in fish. African Journal of Food, Agriculture, Nutrition and Development. 10(10):4202-4218.

Myiazaki $\mathbf{T}$ and Egusa $\mathbf{S}$ : Studies on mycotic granulomatosis in fresh water fishes 1. Mycotic granulomatosis in gold fish. Fish pathology, 1972, 7:15-25.

Olufemi BE: The Aspergilli as pathogens of cultured fishes. In: Recent advances of Aquaculture, (Eds. J.F. Munir and R.J. Roberts). 1983, pp. $193-218$.

Qureshi TA, Chauhan $\mathbf{R}$ and Mastan SA: Haematological investigations on fishes infested with fungal growth. $J$ of Envr. Biol, 2001, 22. (4), 273-276.

Refai MK, Laila A, Mohamed M, Amany M Kenawy and Shimaa SMA: The assement of mycotic settlement of fresh water fishes in Egypt. J. OF American Science 2010, 6(11).
Roberts RJ: The mycology of teleosts, fish pathology. 2nd edition.London ,England. Billere Tyndall, 1989.pp 320-336.

Rodricks, E.G. 1991. Indegenous Pathogen: Vibrionaceae of Microbiology of Marine Food Products. Reinhold, New York, pp.285-295.

Shome R, Shome BR, Sarangi N, Bandopadhyay Ak (1996). Etiological characterization of acute infectious abdominal dropsy outbreak affecting Indian major carp, Cirrhinus mrigala in South Andamans. Curr Sci. 70; pp.744-747.

Slaby, B.M., Martin, R.E., Ramsdell, G.E.1981. Reproducibility of Microbiological counts on frozenCod: A collaborative study. J.Food Sci.46 (3):716-719.

Snieszko SF (1994). The effect of some sulphonamides on the growth of Brook trout, Brown trout and Rainbow trout. Trans Am Fish Soc. 84; 86-92. 